\title{
Compatibility of Mancozeb 75 WP with some plant extracts in the integrated management of Cercospora leaf spot disease of okra (Abelmoschus esculentus (L.) Moench)
}

\author{
V.O. DANIA* \& N. E. SAM \\ (V.O.D \& N.E.S.: Department of Crop Protection and Environmental Biology, University of \\ Ibadan, PMB 001, Ibadan, Nigeria) \\ *Corresponding author's email: victorohileobo@gmail.com
}

\begin{abstract}
The use of synthetic mancozeb fungicide has not been effective in the control of okra leaf spot (Pseudocercospora abelmoschi) disease amidst critical issues of environmental concerns. Therefore, this study evaluated the compatibility of mancozeb 75 WP with some botanicals in the integrated management of the disease. Laboratory assay was a $3 \times 4 \times 2$ factorial laid out in a completely randomized design with three replications, while the field experiment was a randomized complete block design with 14 treatments. Four extract concentrations, 15, 30, 45 and 50\% w/v and $0.5 \mathrm{~g} / 1$ Mancozeb $75 \mathrm{WP}$ were evaluated. The application of Syzygium aromaticum extract at $50 \% \mathrm{w} / \mathrm{v}$ concentration had the highest mycelial growth reduction of $71.89 \%$ of the pathogen. The soil textural class was sandy loam and treatments effect on okra growth indices did not differ significantly $(\mathrm{p}>0.05)$. The highest pod yield of $15.48 \mathrm{t} / \mathrm{ha}^{-1}$ was obtained in treatment inoculated with $P$. abelmoschi. but treated with a combination of $S$. aromaticum and Mancozeb. The same treatment had the lowest disease incidence of $4.01 \%$, while combined application of C. papaya, S. aromaticum and Mancozeb recorded significantly $(p<0.05)$ lower disease severity among inoculated plants. Therefore, this combination is recommended as foliar spray on okra in place of Mancozeb.
\end{abstract}

Keywords: Botanicals; leaf spot disease; Laboratory assay; Mancozeb; Pathogen; Yield Original scientific paper. Received 4 May 2020; revised 4 Sep 2020.

\section{Introduction}

Okra (Abelmoschus esculentus (L.) Moench), is an annual vegetable crop that is generally cultivated for its tender and succulent fruits. Nigeria is the third-largest producer of okra in the world and the crop is also about the third most consumed fruit vegetable in the country after tomato and pepper (Bello \& Aminu, 2017). The immature fruits or pods contain digestible fibre and are used in making stews and soups (Daniela et al., 2012). The unripe fruits lack cholesterol, low in calories and are sources of important minerals like potassium, calcium, vitamins A and C (Reddy et al., 2013; Das et al., 2013). The mucilage from the fruit can be used as a medicinal preparation for plasma replacement or expansion of blood volume circulation (Maksudul et al., 2015).

Fungal diseases constitute a major limiting factor to the growth and yield of okra.

Ghana Jnl Agric. Sci. 55 (2), $26-38$

GJAS is an Open Access Journal and distributed under the terms of the Creative Commons (CC) License [CC BY 4.0] 
These include Cercospora leaf spot, dampingoff, powdery mildew, leaf blight and fruit rot (Farrang, 2011). Leaf spot is an important disease of okra. It limits the photosynthetic potential of the leaves, thereby reducing the overall yield performance of the crop. It is prevalent in West Africa and areas where okra is cultivated in the tropics, especially during the rainy season with high relative humidity. Symptoms of the disease on infected okra usually begin with the appearance of small brown irregular spots surrounded by pink colouration (Kumar et al., 2010). Usually, symptoms first appear on the lower, older leaves while lesion appears on the younger leaves, which become necrotic at an advanced stage of development.

Breeding for resistance is a viable strategy in the prevention of okra leaf spot, but mutation could sometimes cause resistance breakdown in the plant. The disease is mainly controlled by the use of synthetic Mancozeb fungicide, especially in Nigeria. Mancozeb is a broad-spectrum protectant fungicide for the control of a wide range of diseases in crops. However, besides the deleterious effect of this chemical on man and the environment, it gives only short-term disease control and must be applied before fungal spores germinate. Therefore, multiple applications at regular intervals are required for effective control of plant diseases (Dania \& Gbadamosi, 2019). The use of natural plant extracts as biopesticides in the control of plant diseases is cost-effective and harmless to biodiversity (Estrada-Cano et al., 2017).

Carica papaya leaves and seeds are known to contain proteolytic enzymes such as papain, and other secondary metabolites including alkaloids, flavonoids and organic acids which confer anti-bacterial properties on the plant (Adebiyi \& Adaikan, 2005; Doughari et al., 2007). Aqueous extracts from different papaya tissues have exhibited bioactivity against Colletotrichum gloeosporioides causing anthracnose disease of many crops (Bautista-Ban os et al., 2002). The fungicidal effect of Chromolaena odorata (Siam weed) extract has been reported in the control of Colletotrichum coccodes, a rot-causing fungus of tomato fruits (Ngegba et al., 2018). Clove oil obtained from Syzygium aromaticum has useful antimicrobial effects on different types of plant pathogen such as fungi, bacteria and nematodes (El-Samawanty et al., 2013; Mittal et al., 2014; Manganayi et al., 2015). Although the application of mancozeb and each of these botanicals singly could reduce disease incidence, combined application in varying doses within the context of integrated disease management is expected to yield a better outcome. Therefore, this study evaluated the efficacy of combining mancozeb and different plant extracts for the integrated management of okra leaf spot disease.

\section{Materials and Methods}

Experimental site and sample collection

The research was conducted in the Plant Pathology laboratory and crop garden of the Department of Crop Protection and Environmental Biology, University of Ibadan, Nigeria. The University is located between latitude $7^{\circ} 23^{\prime} \mathrm{N}$ and longitude $3^{\circ} 54^{\prime} \mathrm{E}$. The monthly rainfall at the experimental site varied between 137 and $192 \mathrm{~mm}$ with a mean temperature of $27.8^{\circ} \mathrm{C}$ and $86.61 \%$ relative humidity. The Seeds of a susceptible okra cultivar NHLe 47-4 were obtained from the National Horticultural Research Institute (NIHORT), Ibadan, Nigeria. Fresh leaves of Chromolaena odorata and Carica papaya were harvested from the Teaching and Research Farm, University of Ibadan, while 
dried seeds of Syzygium aromaticum and Mancozeb 75\% WP fungicide were purchased from the local market. A pathogenic isolate of Pseudocercospora abelmoschi was obtained from the mycological herbarium of the International Institute of Tropical Agriculture (IITA), Ibadan, Nigeria.

\section{Preparation of aqueous plant extracts}

Fresh leaves of Chromolaena odorata, Carica papaya and seeds of Syzygium aromaticum were washed under running tap water and airdried at $28-30^{\circ} \mathrm{C}$ for 12 days under a laminar flow hood chamber. Four weights 15, 30, 45 and $50 \mathrm{~g}$ of each plant material were pulverized into a smooth powder using a high-speed blender Model KSB 5017SR USA in $100 \mathrm{ml}$ sterile distilled water, and then filtered through a Whatman No. 4 filter paper separately into a $250 \mathrm{ml}$ Erlenmeyer flask to produce 15, 30, 45 and $50 \% \mathrm{w} / \mathrm{v}$ concentrations using cold water as the extraction medium. A synthetic fungicide, Mancozeb 75WP, which served as a positive check was formulated using the manufacturer's instruction at $0.5 \mathrm{~g} / \mathrm{L}$ and applied as an amendment in potato dextrose agar (PDA). A hundred microlitre of Mancozeb was injected into each Petri dish using a $10 \mathrm{ml}$ syringe, mixed with $10 \mathrm{ml}$ PDA and allowed for 30 minutes to gel. The pathogen was inoculated at the centre and mycelial growth was measured for five consecutive days.

\section{Mycelial inhibition assays}

A $3 \times 4 \times 2$ factorial design in a completely randomized design was used with three replicates to determine the best extract concentration that would inhibit the mycelial growth and sporulation of the test fungus and which was subsequently selected for the field trial. The constituents were three factors,
C. odorata, C. papaya and S. aromaticum evaluated at four levels $(15 \%, 30 \%, 45 \%$ and $50 \% \mathrm{w} / \mathrm{v}$ ), two controls, Mancozeb which was a positive check and negative control consisting of pathogen without extract amendment. Pseudocercospora isolate was maintained on potato dextrose agar (PDA) growth medium stored at room temperature $\left(28-30^{\circ} \mathrm{C}\right)$ for four days before use in the antifungal bioassay according to Dania and Omidiora (2019). An aliquot of $100 \mu \mathrm{l}$ of each extract concentration was dispensed at the centre of the Petri dish in triplicates and $10 \mathrm{ml}$ of sterilised PDA added. The mixture was stirred gently to ensure proper mixing. A four-day-old mycelium of the actively growing pathogen was removed using a sterilised 2-cm cork borer inoculated at the centre of the extract-amended PDA in Petri dishes and incubated at $28-30^{\circ} \mathrm{C}$ for seven days. Radial mycelial growth of treatments was measured at 24-hours intervals for five consecutive days post-inoculation using a ruler across two perpendicular lines drawn at the backside of the Petri dish and expressed as the percentage of radial growth of the control (Bautista-Ban os et al., 2002).

Determination of physical and chemical properties of the experimental soil

Five core samples of unsterilised soil were collected from five different points at the arable crop garden in the Department of Crop Protection and Environmental Biology, University of Ibadan, Nigeria and mixed thoroughly to form a composite sample and air-dried at $60^{\circ} \mathrm{C}$ for two days. The soil was not sterilised in this experiment to avoid vapourisation of some nutrient constituents that may have impacted negatively on the results obtained. The soil was sieved through a 2-mm filter mesh preparatory to further analysis. 
Particle size distribution was determined by the hydrometer method (Pauwels et al., 1992). Soil $\mathrm{pH}$ was assessed after mixing $1.0 \mathrm{~g}$ of the soil with $10 \mathrm{ml}$ sterile water and allowed to stand for 12 hours using a Philips $\mathrm{pH}$ meter model PW9215 (Kacar, 1997). Organic carbon (C) content was measured using dichromateoxidation according to the modified method of Walkley and Black (1934). Total nitrogen (N) content was measured using an elemental analyzer (EA 1125 CHNS-0- Zhang, China). Exchangeable potassium $(\mathrm{K})$, calcium $(\mathrm{Ca})$, magnesium $(\mathrm{Mg})$ and sodium $(\mathrm{Na})$, were determined using an Absorption Atomic spectrophotometer UV-VIS 2001-India. The Bray-2 method was used to determine available phosphorus (Fomenky et al., 2018). Total N was determined by Kjeldhal method (Pauwels et al. (1992).

Effect of treatment combinations on growth and yield of okra

Field experiment was conducted at the peak of the rainy season between May and August, 2019. The soil type is a welldrained, flat, sandy loam with a mean monthly temperature of $27.8^{\circ} \mathrm{C}$ (Dania \& Gbadamosi, 2019). The experiment was laid out in a randomized complete block design with three replications and 14 treatments. It consisted of three blocks, each having 14 plots with a total of 42 plots. Each plot had a dimension of $3.2 \times 1.4 \mathrm{~m}$. An alley of $1.0 \mathrm{~m}$ and $0.5 \mathrm{~m}$ was left between the blocks and plots respectively. Plant spacing was $50 \times 60 \mathrm{~cm}$ with six plants per unit plot and 84 plants per block. Four seeds of okra were sowed per hill and later thinned to two at one week after sowing. Plots were kept weed-free by manual weeding throughout the experiment. The treatments consisted of the following combinations:
$\mathrm{T} 1=$ Okra plants inoculated with pathogen only (Control)

$\mathrm{T} 2=$ Uninoculated okra plants

$\mathrm{T} 3=$ Carica papaya

$\mathrm{T} 4=$ Chromolaena odorata

$\mathrm{T} 5=$ Syzygium aromaticum

$\mathrm{T} 6=$ Mancozeb

$\mathrm{T} 7=$ C. papaya + Mancozeb

$\mathrm{T} 8=C$. odorata + Mancozeb

$\mathrm{T} 9=S$. aromaticum + Mancozeb

$\mathrm{T} 10=$ C. papaya + C. odorata + Mancozeb

$\mathrm{T} 11=C$. papaya $+S$. aromaticum + Mancozeb

$\mathrm{T} 12=C$. odorata $+S$. aromaticum + Mancozeb

$\mathrm{T} 13=$ C. papaya + C. odorata + S. aromaticum

$\mathrm{T} 14=$ C. papaya + C. odorata + S. aromaticum

+ Mancozeb

Of the four extract concentrations that were evaluated in the in vitro experiment, $50 \% \mathrm{w} / \mathrm{v}$ concentration of each extract which had the best inhibitory potential in vitro was selected and used in the field trial. Pseudocercospora spore concentration was prepared using the serial dilution method. This was done using two Petri dishes containing pure cultures of $P$. abelmoschi. Nine $100 \mathrm{ml}$ beakers were filled with sterile distilled water up to $90 \mathrm{ml}$ gauge. An aliquot of $0.1 \mathrm{ml}$ Tween 20 was dispensed to the culture and $50 \mathrm{ml}$ of sterile distilled water was used to scoop out the spores and mycelia on each Petri dish into a beaker. The medium in both beakers was decanted through Whatman filter paper No. 4 to collect the spores and remove the mycelia. The medium from both Petri dishes was poured into a beaker to make $100 \mathrm{ml}$ of the inoculum which then served as the stock solution. Ten millilitres were transferred from the stock solution to the $90 \mathrm{ml}$ in the first beaker to make $10^{1}$ concentration. The procedure was used to produce three concentrations $10^{4}, 10^{6}$ and $10^{8}$ and eventually $10^{6}$ was selected as the optimal concentration. 
Healthy okra plants with fully developed first trifoliate leaves were inoculated with an inoculum concentration of $1 \times 10^{6}$ conidia $/ \mathrm{ml}$ of the pathogen at three weeks after sowing according to Dania and Gbadamosi (2019). The treatment combinations were applied as foliar spray at two weeks after inoculation before the appearance of visible symptoms on the okra plants. The aqueous extracts and Mancozeb fungicide were mixed in a 1:1 equal volume ratio prior to application. Second spraying was done four weeks after the first when symptoms had emerged as curative therapy. Data were collected on growth parameters such as plant height, number of leaves, stem girth and yield indices including pod weight, pod length, seed weight, number of seeds per pod and yield per hectare following standard procedures. The field experiment was terminated after collection of all growth and yield data at 90 days after sowing. Fruit yield was determined according to the modified method of Biya (2018)

Fruit yield $/ \mathrm{ha}^{-1}=\frac{\text { Length of row } \times \text { Area of hectare }}{\text { Fruit weight } \times \text { No. of rows per plot } \times \text { spacing }}$

Fruit yield per hectare $\left(\mathrm{kg} / \mathrm{ha}^{-1}\right)$ was divided by a factor of 1000 to convert to tonnes per hectare $\left(\mathrm{t} / \mathrm{ha}^{-1}\right)$.

\section{Determination of incidence and severity}

Disease incidence was measured as the number of the crop population, which was counted as individual plants that were infected and expressed as a percentage of total plants per treatment (Brown \& Kean, 2012). Disease severity was evaluated as the proportion of the area of the plant leaf that showed symptoms of the disease. The assessment was based on visual observation of the leaves of test plants for typical symptom development of brown necrotic lesions. Disease severity was rated on a scale of 1-6 according to the modified method of Inglis et al. (1988):

$1=$ No disease symptom, $2=1-10 \%$ of leaflet area with lesion, $3=11-25 \%$ leaflet area with lesion, $4=26-50 \%$ leaflet area with lesion and limited chlorosis, $5=>50 \%$ of the leaflet area with lesion and sporadic necrosis and $6=$ Defoliation.

From the rating scale, disease index (DI) was calculated according to the method described by Nagesh and Mudge (2017):

DI $(\%)=100 . \Sigma[(f . v) /(n . x)]$, where, $f=$ number of plants with the same grade; $v=$ observed grade; $n=$ total number of plants evaluated and $\mathrm{x}=$ maximum grade on the scale.

Data were collected progressively on disease incidence and severity beginning at two weeks after inoculation (WAI) and continued at $4,6,8$ and 10 WAI all through the growth stages The final data recorded at 10WAI was selected and used in data analysis.

\section{Statistical analysis}

Data were subjected to one-way analysis of variance (ANOVA) using the Generalized Linear Model (GLM) procedure of the Statistical Analysis System (SAS) Version 9.4. Significant differences among means were separated using the Duncan's Multiple Range Test (DMRT) at 5\% level of probability.

\section{Results}

\section{Mycelial inhibition assay}

The application of the plant extracts significantly $(p<0.05)$ reduced the mycelial growth of the test fungus with increasing extract concentration (Table 1). Growth inhibition of the pathogen in Petri dishes varied from 18.56$37.01 \%$ at $15 \% \mathrm{w} / \mathrm{v}$ concentration of C. papaya, C. odorata and S. aromaticum. Compared to all the test botanicals, S. aromaticum extract had a significant mycelial reduction of $71.89 \%$ 
at $30 \% \mathrm{w} / \mathrm{v}$. The extract completely inhibited pathogen growth as the concentration was increased to 45 and $50 \% \mathrm{w} / \mathrm{v}$. Carica papaya extract inhibited Pseudocercospora growth by $74.78 \%$ and was more effective than $C$. odorata at $50 \% \mathrm{w} / \mathrm{v}$ concentration. Mancozeb
75 WP amended plates completely inhibited growth of the pathogen. Comparatively, there was zero inhibition in the control treatment without extract application.

TABLE 1

Inhibitory effect of botanicals on mycelial growth of Pseudocercospora abelmoschi

\begin{tabular}{llc}
\hline Treatment & Mycelial growth $(\mathrm{cm})$ & Inhibition (\%) \\
\hline Control & $9.0 \mathrm{a}$ & $0.0 \mathrm{c}$ \\
$15 \%$ Carica papaya & $7.33 \mathrm{a}$ & $18.56 \mathrm{bc}$ \\
$15 \%$ Chromolaena odorata & $6.08 \mathrm{a}$ & $32.44 \mathrm{~b}$ \\
$15 \%$ Syzygium aromaticum & $5.71 \mathrm{ab}$ & $37.01 \mathrm{~b}$ \\
$30 \%$ Carica papaya & $5.01 \mathrm{ab}$ & $44.33 \mathrm{~b}$ \\
$30 \%$ Chromolaena odorata & $5.23 \mathrm{ab}$ & $41.89 \mathrm{~b}$ \\
$30 \%$ Syzygium aromaticum & $2.53 \mathrm{~b}$ & $71.89 \mathrm{ab}$ \\
$45 \%$ Carica papaya & $3.72 \mathrm{ab}$ & $58.67 \mathrm{ab}$ \\
$45 \%$ Chromolaena odorata & $4.6 \mathrm{ab}$ & $48.89 \mathrm{ab}$ \\
$45 \%$ Syzygium aromaticum & $0.0 \mathrm{bc}$ & $100 \mathrm{a}$ \\
$50 \%$ Carica papaya & $2.27 \mathrm{~b}$ & $74.78 \mathrm{ab}$ \\
$50 \%$ Chromolaena odorata & $3.74 \mathrm{~b}$ & $58.45 \mathrm{ab}$ \\
$50 \%$ Syzygium aromaticum & $0.0 \mathrm{bc}$ & $100 \mathrm{a}$ \\
Mancozeb & $0.0 \mathrm{bc}$ & $100 \mathrm{a}$ \\
\hline
\end{tabular}

Means with same letters along a column are not significantly different using DMRT test at $\mathrm{P}<0.05$.

Determination of physical and chemical properties of the experimental soil

The experimental soil comprised $7.2 \%$ silt, $81.31 \%$ sand and $11.5 \%$ clay, belonging to the sandy loam textural class (Table 2). It had a slightly acidic $\mathrm{pH}$ of 5.39 and contained average proportions of the major macronutrients, $\mathrm{N}, \mathrm{P}$ and $\mathrm{K}$, with an organic matter content of $6.05 \%$. Moderate amounts of other micronutrients were also present in the soil. 
TABLE 2

Physical and chemical properties of soil used in the experiment

\begin{tabular}{ll}
\hline Soil parameter & Value \\
Silt $(\%)$ & 7.22 \\
Sand $(\%)$ & 81.31 \\
Clay $(\%)$ & 11.50 \\
Textural class & Sandy loam \\
$\mathrm{pH}$ & 5.39 \\
Organic matter $(\%)$ & 6.05 \\
Organic carbon $(\%)$ & 8.64 \\
Bulk density $\left(\mathrm{kg} / \mathrm{m}^{3}\right)$ & 2.88 \\
Available Phosphorus $(\mathrm{mg} / \mathrm{kg})$ & 10.33 \\
Available Potassium $(\mathrm{Cmol} / \mathrm{kg})$ & 0.72 \\
Total Nitrogen $(\mathrm{Cmol} / \mathrm{kg})$ & 2.50 \\
Copper $(\mathrm{mg} / \mathrm{kg})$ & 2.63 \\
Sodium $(\mathrm{Cmol} / \mathrm{kg})$ & 0.52 \\
Iron $(\mathrm{mg} / \mathrm{kg})$ & 93.04 \\
Manganese $(\mathrm{Cmol} / \mathrm{kg})$ & 102.77 \\
Magnesium $(\mathrm{Cmol} / \mathrm{kg})$ & 1.41 \\
Calcium $(\mathrm{Cmol} / \mathrm{kg})$ & 2.68 \\
CEC $(\mathrm{Cmol} / \mathrm{kg})$ & 4.08 \\
\hline
\end{tabular}

Effect of treatment combination on growth and yield of okra

Plant height varied between 24.71 and $40.34 \mathrm{~cm}$ at the vegetative stage and increased progressively through the reproductive to maturity stage (Table 3). There was no significant difference $(p>0.05)$ among the treatments in plant height, number of leaves and stem girth. Control plants that were inoculated with the pathogen but without treatment did not differ significantly $(\mathrm{p}>0.05)$ in seed and pod yield characteristics (Table 4). However, inoculated plants that were treated with a combination of $S$. aromaticum and Mancozeb fungicide produced the highest yield of 15.48 $\mathrm{t} / \mathrm{ha}^{-1}$, which was significantly higher than single-dose application of each extract and in the control plants.

Table 3

Effect of treatments on growth performance of okra

\begin{tabular}{|c|c|c|c|c|c|c|c|c|c|}
\hline \multirow[b]{2}{*}{ Treatment } & \multicolumn{3}{|c|}{ Plant height $(\mathrm{cm})$} & \multicolumn{3}{|c|}{ Number of leaves } & \multicolumn{2}{|c|}{ Stem girth $(\mathrm{cm})$} & \multirow[b]{2}{*}{ Maturity } \\
\hline & Veg & Rep & Maturity & Veg & Rep & Maturity & Veg & Rep & \\
\hline Control & $24.71 \mathrm{ab}$ & $53.2 \mathrm{ab}$ & $73.11 \mathrm{ab}$ & $3.82 \mathrm{a}$ & $5.88 \mathrm{a}$ & $6.12 \mathrm{a}$ & $0.77 \mathrm{a}$ & $3.13 \mathrm{a}$ & $4.05 \mathrm{a}$ \\
\hline Uninoculated okra plants & $27.3 \mathrm{ab}$ & $45.22 b$ & $56.62 \mathrm{bc}$ & $4.55 \mathrm{a}$ & $6.44 \mathrm{a}$ & $8.32 \mathrm{a}$ & $1.24 \mathrm{a}$ & $2.57 \mathrm{a}$ & $3.97 \mathrm{a}$ \\
\hline C. papaya & $25.85 \mathrm{ab}$ & $50.08 \mathrm{ab}$ & $71.93 \mathrm{ab}$ & $4.72 \mathrm{a}$ & $5.88 \mathrm{a}$ & $7.14 \mathrm{a}$ & $2.15 \mathrm{a}$ & $4.07 \mathrm{a}$ & $5.03 \mathrm{a}$ \\
\hline C. odorata & $31.77 \mathrm{ab}$ & $57.20 \mathrm{a}$ & $80.61 \mathrm{a}$ & $5.01 \mathrm{a}$ & $7.43 \mathrm{a}$ & $9.05 \mathrm{a}$ & $1.2 \mathrm{a}$ & $2.33 \mathrm{a}$ & $4.31 \mathrm{a}$ \\
\hline S. aromaticum & $36.23 \mathrm{a}$ & $47.88 b$ & $63.55 b$ & $3.51 \mathrm{a}$ & $5.05 \mathrm{a}$ & $8.77 \mathrm{a}$ & $1.33 \mathrm{a}$ & $3.48 \mathrm{a}$ & $4.22 \mathrm{a}$ \\
\hline Mancozeb & $27.41 \mathrm{ab}$ & $45.44 b$ & $60.81 b$ & $4.08 \mathrm{a}$ & $6.54 \mathrm{a}$ & $9.13 \mathrm{a}$ & $1.72 \mathrm{a}$ & $3.95 \mathrm{a}$ & $5.01 \mathrm{a}$ \\
\hline C. papaya + Mancozeb & $40.34 \mathrm{a}$ & $51.67 \mathrm{ab}$ & $79.22 \mathrm{a}$ & $3.95 \mathrm{a}$ & $4.93 \mathrm{a}$ & $6.89 \mathrm{a}$ & $1.65 \mathrm{a}$ & $3.02 \mathrm{a}$ & $4.73 \mathrm{a}$ \\
\hline C. odorata + Mancozeb & $37.21 \mathrm{a}$ & $48.81 b$ & $66.41 b$ & $4.17 \mathrm{a}$ & $5.77 \mathrm{a}$ & $7.44 \mathrm{a}$ & $0.97 \mathrm{a}$ & $2.43 \mathrm{a}$ & $3.85 \mathrm{a}$ \\
\hline S. aromaticum + Mancozeb & $26.40 \mathrm{ab}$ & $43.50 \mathrm{~b}$ & $58.12 \mathrm{bc}$ & $4.22 \mathrm{a}$ & $5.33 \mathrm{a}$ & $8.51 \mathrm{a}$ & $0.85 \mathrm{a}$ & $2.33 \mathrm{a}$ & $4.77 \mathrm{a}$ \\
\hline C. papaya + C. odorata + Mancozeb & $39.22 \mathrm{a}$ & $56.71 \mathrm{a}$ & $81.15 \mathrm{a}$ & $3.66 \mathrm{a}$ & $6.75 \mathrm{a}$ & $8.76 \mathrm{a}$ & $1.74 \mathrm{a}$ & $3.52 \mathrm{a}$ & $4.62 \mathrm{a}$ \\
\hline C. papaya + S. aromaticum + Mancozeb & $38.12 \mathrm{a}$ & $55.84 \mathrm{a}$ & $77.33 \mathrm{a}$ & $3.26 \mathrm{a}$ & $6.03 \mathrm{a}$ & $8.31 \mathrm{a}$ & $1.83 \mathrm{a}$ & $3.14 \mathrm{a}$ & $4.73 \mathrm{a}$ \\
\hline C. odorata + S. aromaticum + Mancozeb & $36.11 \mathrm{a}$ & $46.60 \mathrm{~b}$ & $73.87 \mathrm{ab}$ & $4.01 \mathrm{a}$ & $5.60 \mathrm{a}$ & $7.80 \mathrm{a}$ & $0.82 \mathrm{a}$ & $3.21 \mathrm{a}$ & $4.11 \mathrm{a}$ \\
\hline C. papaya $+C$. odorata $+S$. aromaticum & $39.40 \mathrm{a}$ & $52.44 \mathrm{ab}$ & $66.21 \mathrm{~b}$ & $4.31 \mathrm{a}$ & $6.45 \mathrm{a}$ & $8.13 \mathrm{a}$ & $1.34 \mathrm{a}$ & $3.65 \mathrm{a}$ & $4.39 \mathrm{a}$ \\
\hline C. papaya + C. odorata + S. aromaticum + Mancozeb & $32.77 \mathrm{ab}$ & $45.32 b$ & $74.04 \mathrm{ab}$ & $4.35 \mathrm{a}$ & $5.51 \mathrm{a}$ & $9.06 \mathrm{a}$ & $1.55 \mathrm{a}$ & $2.98 \mathrm{a}$ & $5.0 \mathrm{a}$ \\
\hline
\end{tabular}

Veg $=$ Vegetative growth stage, Rep $=$ Reproductive growth stage

Means with same letters along a column are not significantly different using DMRT test at $\mathrm{P}<0.05$.

Each extract was at 50\% w/v concentration and Mancozeb $75 \mathrm{WP}$ at $0.5 \mathrm{~g} / \mathrm{l}$. 
TABLE 4

Effect of treatments on yield of okra inoculated with Pseudocercospora abelmoschi

\begin{tabular}{|c|c|c|c|c|c|c|c|}
\hline Treatment & $\begin{array}{l}\text { Pod wt } \\
(g)\end{array}$ & $\begin{array}{l}\text { Pod length } \\
(\mathrm{cm})\end{array}$ & $\begin{array}{l}\text { Pod } \\
\text { width } \\
\text { (cm) }\end{array}$ & $\begin{array}{l}100 \text { seed } \\
w t(g)\end{array}$ & $\begin{array}{l}\text { Seeds } \\
\text { per } \\
\text { pod }\end{array}$ & $\begin{array}{l}\text { No. of } \\
\text { pods/ } \\
\text { Plant }\end{array}$ & $\begin{array}{l}\text { Yield } \\
\left(\mathrm{t} / \mathrm{ha}^{-I}\right.\end{array}$ \\
\hline Control & $11.72 \mathrm{a}$ & $10.75 \mathrm{ab}$ & $7.21 \mathrm{a}$ & $50.86 \mathrm{a}$ & $26.32 \mathrm{ab}$ & $6.74 \mathrm{a}$ & $6.87 \mathrm{~b}$ \\
\hline Uninoculated okra plants & $14.81 \mathrm{a}$ & $12.37 \mathrm{a}$ & $5.06 \mathrm{a}$ & $54.76 \mathrm{a}$ & $31.86 \mathrm{ab}$ & $8.15 \mathrm{a}$ & $10.33 \mathrm{ab}$ \\
\hline Carica papaya & $16.08 \mathrm{a}$ & $13.78 \mathrm{a}$ & $4.83 \mathrm{a}$ & $51.45 \mathrm{a}$ & $40.73 \mathrm{a}$ & $6.17 \mathrm{a}$ & $8.21 \mathrm{ab}$ \\
\hline C. odorata & $10.24 \mathrm{a}$ & $15.72 \mathrm{a}$ & $8.17 \mathrm{a}$ & $44.51 \mathrm{ab}$ & $29.33 \mathrm{ab}$ & $9.88 \mathrm{a}$ & $9.23 \mathrm{ab}$ \\
\hline S. aromaticum & $12.34 \mathrm{a}$ & $10.83 \mathrm{ab}$ & $6.33 \mathrm{a}$ & $40.80 \mathrm{ab}$ & $36.11 \mathrm{a}$ & $6.77 \mathrm{a}$ & $7.55 \mathrm{~b}$ \\
\hline Mancozeb & $15.22 \mathrm{a}$ & $15.73 a$ & $5.64 \mathrm{a}$ & $46.77 \mathrm{ab}$ & $26.32 \mathrm{ab}$ & $5.39 \mathrm{a}$ & $11.65 \mathrm{ab}$ \\
\hline Carica papaya + Mancozeb & $16.73 a$ & $8.78 \mathrm{ab}$ & $7.65 \mathrm{a}$ & $49.43 a$ & $31.71 \mathrm{ab}$ & $4.33 \mathrm{a}$ & $8.46 \mathrm{~b}$ \\
\hline Chromolaena odorata + Mancozeb & $17.23 \mathrm{a}$ & $14.77 \mathrm{a}$ & $9.41 \mathrm{a}$ & $48.33 \mathrm{a}$ & $36.88 \mathrm{a}$ & $8.93 \mathrm{a}$ & $11.17 \mathrm{ab}$ \\
\hline Syzygium aromaticum + Mancozeb & $12.13 \mathrm{a}$ & $14.66 \mathrm{a}$ & $8.55 \mathrm{a}$ & $45.50 \mathrm{ab}$ & $26.77 \mathrm{ab}$ & $6.07 \mathrm{a}$ & $15.48 \mathrm{a}$ \\
\hline C. papaya + C. odorata + Mancozeb & $14.88 \mathrm{a}$ & $11.69 \mathrm{ab}$ & $6.09 \mathrm{a}$ & $52.21 \mathrm{a}$ & $35.44 \mathrm{a}$ & $7.77 \mathrm{a}$ & $12.45 \mathrm{a}$ \\
\hline C. papaya + S. aromaticum + Mancozeb & $13.41 \mathrm{a}$ & $15.08 \mathrm{a}$ & $8.40 \mathrm{a}$ & $56.04 \mathrm{a}$ & $33.10 \mathrm{ab}$ & $8.62 \mathrm{a}$ & $10.0 \mathrm{ab}$ \\
\hline C. odorata $+S$. aromaticum + Mancozeb & $15.07 \mathrm{a}$ & $14.01 \mathrm{a}$ & $6.07 \mathrm{a}$ & $48.20 \mathrm{a}$ & $37.20 \mathrm{a}$ & $6.04 \mathrm{a}$ & $10.22 \mathrm{ab}$ \\
\hline C. papaya + C. odorata + S. aromaticum & $16.31 \mathrm{a}$ & $15.44 \mathrm{a}$ & $5.81 \mathrm{a}$ & $51.62 \mathrm{a}$ & $34.03 \mathrm{ab}$ & $6.06 \mathrm{a}$ & $13.08 \mathrm{a}$ \\
\hline C. papava $+C$. odorata $+S$. aromaticum + Mancozeb & $15.41 \mathrm{a}$ & $15.03 \mathrm{a}$ & $7.32 \mathrm{a}$ & $46.03 \mathrm{ab}$ & $41.22 \mathrm{a}$ & $6.02 \mathrm{a}$ & $13.77 \mathrm{a}$ \\
\hline
\end{tabular}

Means with same letters along a column are not significantly different using DMRT test at $\mathrm{P}<0.05$.Each extract was $50 \% \mathrm{w} / \mathrm{v}$ concentration and Mancozeb $75 \mathrm{WP}$ at $0.5 \mathrm{~g} / \mathrm{l}$.

Determination of incidence and severity

Plants inoculated with the pathogen and treated with a combination of $50 \% \mathrm{w} / \mathrm{v}$ S. aromaticum and $0.5 \mathrm{~g} / 1$ Mancozeb $75 \mathrm{WP}$ fungicide had the lowest incidence of $4.01 \%$ at maturity, while plants treated with sole extracts had higher incidences that varied between 11.31 and $15.24 \%$. (Table 5). The treatments differed significantly $(\mathrm{p}<0.05)$ in their inhibitory ability of leaf spot disease with control plants having the highest incidence of $24.77 \%$. Similarly, disease severity was significantly $(\mathrm{p}<0.05)$ lower in plants treated with extract and Mancozeb combination at the various stages of growth, including the positive check relative to control. Disease severity reduction among the treatments was significantly $(\mathrm{p}<0.05)$ higher than control plants that were inoculated with the pathogen without the application of extracts. Percent disease index (PDI) varied between 5.0 and $24.28 \%$ and control plants had significantly higher PDI than other treatments. 
TABLE 5

Effect of treatments on incidence and severity of leaf spot disease of okra

\begin{tabular}{|c|c|c|c|c|c|c|c|}
\hline \multirow[b]{2}{*}{ Treatment } & \multicolumn{3}{|c|}{ Disease incidence } & \multicolumn{2}{|c|}{ Disease severity } & \multirow[b]{2}{*}{ Maturity } & \multirow[b]{2}{*}{$D I(\%)$} \\
\hline & Vegetative & Reproductive & Maturity & Vegetative & Reproductive & & \\
\hline Control & $17.85 \mathrm{a}$ & $23.46 \mathrm{a}$ & $24.77 \mathrm{a}$ & $4.30 \mathrm{a}$ & $4.50 \mathrm{a}$ & $4.50 \mathrm{a}$ & $24.28 \mathrm{a}$ \\
\hline Uninoculated okra plants & $0.0 \mathrm{~b}$ & $0.0 \mathrm{~b}$ & $0.0 \mathrm{c}$ & $1.0 \mathrm{~b}$ & $1.0 \mathrm{~b}$ & $1.0 \mathrm{~b}$ & $0.0 \mathrm{~d}$ \\
\hline Carica papaya & $5.28 \mathrm{ab}$ & $7.24 \mathrm{ab}$ & $15.24 \mathrm{ab}$ & $2.22 \mathrm{ab}$ & $3.10 \mathrm{ab}$ & $3.40 \mathrm{ab}$ & $18.33 \mathrm{ab}$ \\
\hline Chromolaena odorata & $2.8 \mathrm{ab}$ & $4.22 \mathrm{ab}$ & $13.87 \mathrm{ab}$ & $2.81 \mathrm{ab}$ & $2.8 \mathrm{ab}$ & $3.02 \mathrm{ab}$ & $17.26 \mathrm{ab}$ \\
\hline Syzygium aromaticum & $3.77 \mathrm{ab}$ & $5.31 \mathrm{ab}$ & $11.31 \mathrm{ab}$ & $2.31 \mathrm{ab}$ & $2.55 \mathrm{ab}$ & $2.85 \mathrm{ab}$ & $12.43 \mathrm{~b}$ \\
\hline Mancozeb & $0.74 \mathrm{ab}$ & $2.8 \mathrm{ab}$ & $8.10 \mathrm{~b}$ & $1.43 \mathrm{ab}$ & $2.77 \mathrm{ab}$ & $2.94 \mathrm{ab}$ & $13.08 \mathrm{~b}$ \\
\hline Carica papaya + Mancozeb & $1.83 \mathrm{ab}$ & $2.51 \mathrm{ab}$ & $7.67 \mathrm{~b}$ & $1.66 \mathrm{ab}$ & $1.95 \mathrm{bc}$ & $2.07 \mathrm{~b}$ & $10.24 \mathrm{~b}$ \\
\hline Chromolaena odorata + Mancozeb & $2.56 \mathrm{ab}$ & $3.09 \mathrm{ab}$ & $9.22 b$ & $1.20 \mathrm{ab}$ & $2.07 \mathrm{bc}$ & $2.15 b$ & $9.07 \mathrm{bc}$ \\
\hline Syzygium aromaticum + Mancozeb & $0.41 \mathrm{ab}$ & $2.74 \mathrm{ab}$ & $4.01 \mathrm{bc}$ & $1.20 \mathrm{ab}$ & $1.88 \mathrm{bc}$ & $1.94 \mathrm{~b}$ & $5.03 \mathrm{c}$ \\
\hline C. papaya + C. odorata + Mancozeb & $1.80 \mathrm{ab}$ & $3.40 \mathrm{ab}$ & $9.70 \mathrm{~b}$ & $1.23 \mathrm{ab}$ & $1.78 \mathrm{bc}$ & $3.40 \mathrm{ab}$ & $18.33 \mathrm{ab}$ \\
\hline C. papaya + S. aromaticum + Mancozeb & $1.22 \mathrm{ab}$ & $2.04 \mathrm{ab}$ & $7.35 \mathrm{~b}$ & $1.13 \mathrm{ab}$ & $1.77 \mathrm{bc}$ & $1.88 \mathrm{~b}$ & $2.86 \mathrm{~cd}$ \\
\hline C. odorata + S. aromaticum + Mancozeb & $0.81 \mathrm{ab}$ & $1.23 \mathrm{ab}$ & $7.13 b$ & $1.1 \mathrm{ab}$ & $1.55 \mathrm{c}$ & $2.0 \mathrm{~b}$ & $8.77 \mathrm{bc}$ \\
\hline C. papaya + C. odorata $+S$. aromaticum & $0.55 \mathrm{ab}$ & $1.08 \mathrm{ab}$ & $6.77 \mathrm{ab}$ & $1.23 \mathrm{ab}$ & $1.37 \mathrm{c}$ & $1.90 \mathrm{~b}$ & $8.04 \mathrm{bc}$ \\
\hline C. papaya + C. odorata + S. aromaticum + Mancozeb & $0.63 \mathrm{ab}$ & $1.30 \mathrm{ab}$ & $6.84 \mathrm{ab}$ & $1.28 \mathrm{ab}$ & $1.42 \mathrm{c}$ & $1.94 \mathrm{~b}$ & $8.23 \mathrm{bc}$ \\
\hline
\end{tabular}

Means with same letters along a column are not significantly different using DMRT test at $\mathrm{P}<0.05$.

$1=$ No disease symptom, $2=1-10 \%$ of leaflet area with lesion, $3=11-25 \%$ leaflet area with lesion, $4=26-50 \%$ leaflet area with lesion and limited chlorosis, $5=>50 \%$ of the leaflet area with lesion and sporadic necrosis and 6= Defoliation.

Each extract was at 50\% w/v concentration and Mancozeb $75 \mathrm{WP}$ at $0.5 \mathrm{~g} / \mathrm{l}$.

\section{Discussion}

Physical and chemical properties of the experimental soil showed that it belonged to the sandy loam textural class, contained moderate quantity of the major macronutrients, $\mathrm{N}, \mathrm{P}, \mathrm{K}$ and organic matter. Soil is a complex matter and comprises minerals, organic matter, water, and air. These fractions greatly influence their texture, structure, and porosity, which subsequently affect air and water movement in the soil layers, and thus the soil's ability to function. Therefore, soil physical and chemical properties have a great influence on soil quality and crop growth and yield performance (Watanabe et al., 2015). The textural category of soil is decided by the relative amount of various particle sizes in soil, that is, whether it is sandy loam, clay or loam. The sandy loam used in this experiment was well-drained, aerated and contained significant amount of organic matter which may have enhanced the growth of the okra plants, hence the application of manure was unnecessary.

Carica papaya extract significantly $(\mathrm{p}<0.05)$ reduced radial mycelial growth of Pseudocercospora sp. at increasing concentrations in the in vitro assay. This result agrees with previous reports of Chiejina and Ukeh (2013) that fungitoxicity of plant extracts is concentration dependent. The variation in the efficacy of the extracts may be attributed to the inherent active ingredient constituents. The main secondary metabolites produced by plant extracts include phenols, flavonoids, alkaloids, saponins, tannins and steroids (Seseni et al., 2015) and their fungicidal properties against various plant pathogens have been reported (Dania \& Thomas, 2019). Carica papaya 
leaves contain alkaloids which are important elements in plant defence system against plant pathogens (Azarkan et al., 2004). Also, latex constituent in papaya leaves contains chitinase enzymes, which have been shown to have strong antifungal activity against biochemical processes in fungi (Chen et al., 2007; Nwinyi et al., 2010). Although no analyses were done in this study to identify chitinase in the extract, these enzymes may have enhanced its antifungal activity against the test pathogen. Though C. odorata was the least effective among the test extracts, it however reduced the mycelial growth of the pathogen by $58.45 \%$. IkechiNwogu et al. (2018) had reported the efficacy of $C$. odorata extract in the management of post-harvest biodeterioration of onions.

The use of botanicals in the management of plant diseases has been reported as an economically sound approach (Farrang, 2011; El-Mohamedy et al., 2013; Dania \& Gbadamosi 2019). The various treatment combinations significantly reduced the incidence of okra leaf spot disease at maturity, while severity showed mild to moderate expression of visible symptoms relative to control. However, the lowest disease incidence of $4.01 \%$ was recorded in plants that were inoculated and treated with a combination of $S$. aromaticum and mancozeb. This result is consistent with the previous findings of Kumar et al. (2017) that reported the efficacy of combining Mancozeb fungicide with neem (Azadiractha indica) and garlic (Allium sativum) in the integrated management of Rhizoctonia solani causing sheath blight of rice. Estrada-Cano et al. (2017) reported the potential of clove oil obtained from $S$. aromaticum in reducing the incidence and severity of Fusarium wilt disease in tomato grown under greenhouse conditions. Similarly,
Seseni et al. (2015) showed the efficacy of the essential oil in inhibiting the prevalence of the damping-off disease among pine seedlings.

Plant height was not significantly influenced by the different treatment combinations that were evaluated in this study. This result is consistent with the findings of Dania and Omidiora (2019) who reported that the application of garlic extract as treatment for damping-off disease did not significantly influence growth parameters in tomato plants. However, it disagrees with report of Thabet and Khalifa (2018) that $S$. aromaticum extract treatment used in the control of Rhizoctonia solani strains in tomato enhanced plant height, root and shoot fresh weights of the crop. The disparity in the ability of certain plant extracts to increase plant growth may be due to elicitor's effect on physiological processes in plants such as ion uptake, cell division, enzymatic activation and protein synthesis (ElMohamedy et al., 2013).

Leaf spot disease is characterized by self-limiting necrotic lesions which reduces the leaf area available for photosynthetic and ultimate yield of infected plants. This was evident in the control which consisted of okra plants that were inoculated with the test pathogen and untreated having the lowest yield of $6.87 \mathrm{t} / \mathrm{ha}^{-1}$. Okra yield was significantly $(\mathrm{p}<0.05)$ higher among treatments that were inoculated and treated with a combination of extract sprays and the synthetic Mancozeb fungicide which served as a positive check. Inoculated plants that were sprayed and treated with a combination of $50 \% \mathrm{w} / \mathrm{v}$ of $S$. aromaticum extract and $0.5 \mathrm{~g} / 1$ mancozeb WP produced the highest yield of $15.48 \mathrm{t} / \mathrm{ha}^{-1}$. This result agrees with the previous reports of Dania \& Omidiora (2019) that the combination of treatments as an integrated approach has the 
overall effect of reducing disease index and boosting obtainable yield among tomato plants.

\section{Conclusion}

This study shows the efficacy of combining readily available and ecologically safe botanicals with synthetic mancozeb fungicide in the management of incidence and severity of leaf spot disease of okra. The combinations enhanced better control of the disease than the single application of mancozeb or single extract application, thus providing a credible and firm basis for an integrated approach in the management of the disease. The technology is quite simple and can easily be adopted by rural farmers who are the target beneficiary of agricultural research.

\section{REFERENCES}

Adebiyi, A. \& Adaikan, P. (2005) Modulation of jejunal contractions by extract of Carica papaya L. seeds. Phytotherapy Research 19, $628-632$.

Azarkan, M., Wintjen, R., Looze, Y. \& BaeyensVolant, D (2004) Detection of three wound-induced proteins in papaya latex. Phytochemistry 65, 525 - 534.

Bello, B.O. \& Aminu, D. (2017) Genetic relationships among okra (Abelmoschus esculentus (L.) Moench) cultivars in Nigeria. Acta agriculturae Slovenica 109, $251-260$.

\section{Bautista-Baños, S., Barrera-Necha, L.L., Bravo-} Luna, I. \& BermudesTorres, L. (2002) Antifungal activity of leaf and stem extracts from various plant species on the incidence of Colletotrichum gloeosporioides of papaya and mango fruit after storage. Revista Mexicana Fitopatologia 20, 8 - 12 .

Biya, M. (2018) Determination of nitrogen and phoshorous fertilizer requirement for sorghum (Sorghum bicolor (L.) Moench production in Kersa- Jimma Zone of Ethiopia, East Africa Journal of Biology, Agriculture and Healthcare 8 (7), 1 - 22.

Brown, J. \& Keane, P. (2012) Assessment of disease and effects on yield. Accessed online Aug 21, 2014 at http://www.appsnet.org/publications/.

Chen, Y.T., Hsu, L.H., Huang, I.P., Tsai, T.C., Lee, G.C. \& Shaw, J.F. (2007) Gene cloning and characterization of a novel recombinant antifungal chitinase from papaya (Carica papaya). Journal of Agricultural and Food Chemistry 55, $714-722$.

Chiejina, N.V. \& Ukeh, J.A. (2013) Efficacy of Aframomum melegueta and Zingiber officinale extracts on fungal pathogens of tomato fruits. Journal of Research in Bioscience 4 (6), 13 16.

Dania, V.O. \& Gbadamosi, L.O. (2019) Efficacy of combined application of Trichoderma asperellum NG T158, Aloe vera leaf extract and poultry manure for the management of Colletotrichum lindemuthianum causing anthracnose disease on cowpea. Archives of Phytopathology and Plant Protection 52 (1 2), $90-107$.

Dania, V. O. \& Omidiora, J. A. (2019) Combination of biological control agents and garlic (Allium sativum) extract in reducing damping-off disease of tomato. Bangladesh Journal of Agricultural 44 (3), 553 - 567.

Dania, V. O. \& Thomas, A. S. (2019) Bioactivity and Phytochemical Composition of Moringa oleifera in the management of fungal rot disease of orange-fleshed sweet potato. Nigerian Journal of Mycology 11, 26 - 45.

Daniela, F. O., Alicia, M., Alicia, R.C., Rodolfo, H. \& Sonia, Z.V. (2012) Quality attributes of okra (Abelmoschus esculentus (L.) Moench) pods as affected by cultivar and fruit size. Journal of Food Research 1 (4), 224 - 235. 
Das, S, A., Chattopadhyay, S. B., Chattopadhyay, S., Dutta, H. \& Hazra, P. (2013) Breeding okra for higher productivity and yellow vein mosaic tolerance. International Journal of Vegetable Science 19, 58 - 77.

Doughari, J.H., Elmahmood, A.M. \& Manzara, S. (2007) Studies on the antibacterial activity of root extracts of Carica papaya L. African Journal of Microbiology Research 1, 37 - 41.

El-Mohamedy, S.R., Abdel-Kader, M.M., AbdEI- Kareem, F. \& El-Mougy, N.S. (2013) Essential oils, inorganic acids and potassium salts as control measures against the growth of tomato root rot pathogens in vitro. Journal of Agricultural Technology 9, 1507 - 1520.

El-Samawaty, A.M., Yassin, M.A., Moslem, M.A. \& Omar, M.R. (2013) Effectiveness of some plant extracts against Fusarium spp. causing cotton seedling damping-off. Life Science Journal 10, 510 - 515 .

Estrada-Cano, C., Anaya-Castro, M.A. MuñozCastellanos, L., Amaya- Olivas, N. \& García-Triana, A. (2017) Antifungal activity of micro capsulated clove (Eugenia caryophyllata) and mexican Oregano (Lippia berlandieri) essential oils against Fusarium oxysporum. Journal of Microbial and Biochemical Technology 9, 567 - 571.

Farrang, E.S.H. (2011) First record of Cercospora leaf spot disease on okra plants and its control in Egypt. Plant Pathology Journal 10 (4), 175 -180 .

Fomenky N.N., Tening, A.S., Chuyong, G.B., Mbene, K., Asongwe, G.A. \& Che, V.B. (2018) Selected physicochemical properties and quality of soils around some rivers of Cameroon. Journal of Soil Science and Environmental Management 9(5), 68 - 80.

Ikechi - Nwogu, C. G., Ukomadu, J., Ezediolu, B. C. \& Okere, S.E (2018) Antifungal activity of Siam weed (Chromoleana odorata (L.) and woodland tobacco (Nicotiana sylvestris (Speg \& Comes) against phytopathogenic fungus of onions (Allium cepa L.) bulb. International Journal of Agricultural and Rural Development 21 (2), 3801 - 3806.

Inglis, D.A., Haedorn, D.J. \& Rand, R.E. (1988) Use of dry inoculum to evaluate beans for resistance to anthracnose and angular leaf spot. Plant Disease 72, 771 - 774.

Kacar, B. (1997) Chemical Analyses of Plant and Soils. AU Agriculture Faculty Publication, p.705.

Kumar, S., Dagnoko, S., Haougui, A., Ratnadass, A., Pasternak, D. \& Kouame, C. (2010) Okra (Abelmoschus spp.) in West and Central Africa: Potential and progress on its improvement. African Journal of Agricultural Research 5, $3590-3598$.

Kumar, V., Chaudhary, V.P., Kumar, D., Kumar, A., Saga, S. \& Chaudhary, S. (2017) Efficacy of botanicals and fungicides against Rhizoctonia solani inciting sheath blight disease on Rice (Oryza sativa L.). Journal of Applied and Natural Science 9 (4), 1916 -1920.

Maksudul, H., Rashid, H.O. \& Pervin, E. (2015) Effect of the combination of cow dung and poultry litter on the yield of okra (Abelmoschus esculentus L.). Basic Research Journal of Agricultural Science and Review 4 (7), 193 198.

Manganyi, M.C., Regnier, T. \& Olivier, E.J. (2015) Antimicrobial activities of selected essential oils against Fusarium oxysporum isolates and their biofilms. South African Journal of Botany 99, 115 - 121.

Mittal, M., Gupta, M., Parashar, P., Mehra, V. \& Khatri, M. (2014) Phytochemical evaluation and pharmacological activity of Syzygium aromaticum: A comprehensive review. International Journal of Pharmacy and Pharmaceutical Sciences 6 (8), 67 - 72. 
Nagesh, G.C. \& Mulge, R. (2017) Screening of okra genotypes against Fusarium wilt disease. International Journal of Current Microbiology and Applied Sciences 6 (11), 1554 - 1558.

Ngegba, P. M., Kanneh, S. M., Bayon, M. S., Ndoko, E. J. \& Musa, P. D. (2018) Fungicidal effect of three plants extracts in control of four phytopathogenic fungi of tomato (Lycopersicum esculentum L.) fruit rot. International Journal of Environment, Agriculture and Biotechnology 3 (1), 112 117.

Nwinyi, O. C. \& Abikoye, B.A. (2010) Antifungal effects of pawpaw seed extracts and papain on post-harvest Carica papaya L. fruit rot. African Journal of Agricultural Research 5 (12), $1531-1535$.

Pauwels, J.M., Ranst, V.E., Verloo, M. \& MvondoZe, A.D. (1992) Manuel de Laboratoire de pédologie. Publications Agricoles $\mathrm{N}^{\circ} 28$. Bruxelles. AGCD. p. 265.

Reddy, M. T., Babu, K.H., Ganesh, M., Begum, H., Reddy, R.S.K. \& Babu, J.D. (2013) Exploitation of hybrid vigour for yield and its components in okra [Abelmoschus esculentus (L.) Moench]. American Journal of Agricultural Science and Technology 1, 1-17.

Seseni, L., Regnier, T., Roux-van der Merwe. M.P., Mogale, E. \& Badenhorst, J. (2015) Control of Fusarium spp. causing damping-off of pine seedlings by means of essential oils. Industrial Crops and Products 76, 329 - 332.

Thabet, M. \& Khalifa, W. (2018) Antifungal activities of clove oil against root rot and wilt pathogens of tomato plants. American-Eurasian Journal of Agricultural and Environmental Sciences 18 (3), $105-114$.

Walkley, A. \& Black, A.I. (1934) An examination of the Degtjareff method for determining soil organic matter, and a proposed modification of the chromic acid titration method. Soil Science 37 (1), $29-38$.

Watanabe, Y., Kikuno, H., Robert, Asiedu, R., Masunaga, T. \& Wakatsuki, T. (2015) Comparison of physicochemical properties of soils under contrasting land use systems in Southwestern Nigeria. Japan Agricultural Research Quarterly 49 (4), 319 - 331. 